\title{
THE IMPORTANCE OF MULTICULTURAL EDUCATION AS A MORAL IMPROVEMENT OF THE NATION
}

\author{
Putri Ega Sabira ${ }^{1}$, Moses Glorino Rumambo Pandin ${ }^{2}$ \\ ${ }^{1}$ Faculty of Economics and Business, Airlangga University Surabaya, Indonesia \\ ${ }^{2}$ Faculty of Cultural Sciences, Airlangga University Surabaya, Indonesia \\ Putri.ega.sabira-2020@feb.unair.ac.id and moses.glorino@fib.unair.ac.id
}

\begin{abstract}
Introduction: Indonesia consists of a plural society with different ethnic, religious, racial, skin color, and other cultures. The difference must be understood by everyone, especially the younger generation in the digital age. If the younger generation does not have a sufficient understanding of multicultural education values, it will impact the moral crisis of the Indonesian nation. This research emphasizes the importance of multicultural education to the younger generation to understand the differences (pluralism) in society and respect them. Method: The method uses a qualitative method with the literature review method by collecting data on ten journals published in 2019, 2020, 2021. Results: The rise of socio-cultural conflicts in Indonesia is why applying multicultural values to the younger generation. Multiculturalism is needed to establish morals and sensitivity for a young person in the face of various social problems and symptoms at a growing age. Conclusion: Multicultural education is vital to the younger generation considering Indonesia has diverse nations and cultures. The efforts that can make to improve the morale of the nation's children, namely by learning citizenship education and religious education and utilizing information technology to spread things related to the values of multicultural education to the broader community
\end{abstract}

Keywords: multicultural education, morals, a young generation

\section{INTRODUCTION}

Indonesia can unite because of the diversity of the nation. These differences consist of gender, ethnicity, race, language, creed, color, class, and culture. H.A.R. Tilaar stated that a multicultural society consists of several groups that can potentially lead to the disintegration of the Indonesian nation. Indonesia is like a currency, where one side of diversity can create an advantage because it is an important asset that must be upheld and maintained. However, on the other hand, diversity/plurality backfired for the Indonesian country. Conflicts that often happen today are expressions of the attitude of primordialism and fanaticism of society. It can happen due to a lack of knowledge and understanding of the formation of the beloved Republic of Indonesia. We often find differences between ethnic groups influenced by social status in terms of the economy. For example, the Chinese race tends to act as boss, and the Javanese race plays labor or employee (1). Thus, the need to establish good communication to create equality between nations. A higher understanding of culture will develop a nature of fanaticism, chauvinism, and nativism. Therefore, society must have sufficient knowledge of multiculturalism so that more low or lower cultural perceptions can be eliminated and can appreciate the differences that exist(2). 
Multicultural education in Indonesia is vital to achieving the spirit of nationalism. Considering that the country of Indonesia has a very diverse nation and culture, then society can be easily affected by various traditions that can cause the disintegration of the nation. Various social issues such as discrimination of both beliefs, religions, genders, and ethnicities are a form of decline in the value of democracy in Indonesia that causes a growing awareness of respect for fundamental human values (3).

Recently, we face new problems that affect various aspects of life, be it economic, cultural, political, or educational. Pandemic Covid-19 can bring our country in many changes, such as the offline learning education will be an online system. It can undoubtedly cause culture shock for students because we live in new culture or situation. As a result, the learning process in schools becomes inadequate and results in low competence, skills, and cultural knowledge due to low multiculturalism education (4). The implementation of multicultural education in educational institutions tends to be limited by virtual learning. However, the values of multicultural education can provide provisions to students in living life in the community(5).

Multicultural education is an educational reform effort that aims to provide equal learning opportunities to all national children without distinguishing race, gender, ethnicity, class, religion, etc. One of the efforts to improve plurality is to establish citizenship education in the educational curriculum. Citizenship education designed by the academic curriculum aims to build the character of students. Citizenship education is a multicultural-based discipline that can foster various principles of multiculturalism, such as tolerance, democracy, respect for equal rights, and differences in the community environment that can apply in the family environment, school environment, and community environment. Citizenship education is one of the containers for the younger generation in training responsibilities and roles as good citizens through the learning process in schools (6). In the implementation of the learning, teachers play an essential role in guiding and directing students to shape the character of the nation's children. Therefore, teachers need strategies in implementing learning in the classroom, one of which is the discussion process. Students can think critically and exchange opinions with other students to introduce a multicultural education that emphasizes differences. However, the digital age is causing information to overgrow. Students can easily access information via the internet. That is the challenge faced by teachers. Teachers are required to be technologically literate to guide students in meeting this world $(7,8)$.

In addition to the approach of citizenship education, the younger generation needs to know the values in Islam, a form of multicultural education. Four values in the Quran reflect multicultural values, including infitah (inclusive), tawassuth (moderate), musawah (equality), and tawazun (balance). Multicultural education in Islam aims to create a socialist, religious, and multicultural balance in carrying out world affairs and the afterlife $(9,10)$.

This research emphasizes the importance of multicultural education to the younger generation in the face of plurality in Indonesia. This problem is important to research to shape character and provide solutions to cases contrary to multicultural education. Based on the information, the author intends to be more in-depth about whether multicultural education plays an important role in shaping the character of millennials? And how can solutions be done as an effort to prevent cases caused by pluralism in Indonesia? 


\section{RESEARCH METHODS}

In writing this article, researchers used a qualitative approach to description with literature review methods. According to O' Connor, Sargeant, and Wood, a literature review describes the theory, findings, and previous research articles obtained from reference material to be used as research activities. Researchers use literature review to draw up a clear frame of mind of the formulation of the problem to be researched. LR contains reviews, summaries, and the author's thoughts on several library resources (articles, books, web, etc.)(14). Based on search results through the internet database, 80 corresponding articles were found. Then, the search results were checked for duplication, found 30 articles were issued because they have similarities. After that, the researchers conducted a screening that corresponded to the theme of the study, found the title $(n=50)$, abstract $(n=30)$, and full text $(n=10)$. Thus, researchers used ten articles in the literature review. The data type used in this article is secondary data. The object of the study of the writing of this article is multicultural education as one of the efforts to establish the moral of the nation's children. The subject of this research study is millennials as the future successors of the Indonesian nation. Literature search, performed with Boolean operators using keywords followed by commands (AND, OR, AND NOT). The keywords used are "multicultural education", "character education", "moral", "younger generation".

Table 1 Keyword Search Literature Review

\begin{tabular}{|l|l|l|}
\hline Multicultural Education & morals & Young Generation \\
\hline OR & OR & OR \\
\hline $\begin{array}{l}\text { the urgency of multicultural } \\
\text { education }\end{array}$ & the nation's moral crisis & $\begin{array}{l}\text { children of the Indonesia } \\
\text { nation }\end{array}$ \\
\hline OR & OR & OR \\
\hline Multiculturalism & the morality of the nation & generation Z \\
\hline
\end{tabular}

Here is a table of article inclusion and exclusion criteria.

Table 2 Exclusion Inclusion Criteria

\begin{tabular}{|l|l|l|}
\hline Criteria & Inclusion & Exclusion \\
\hline Population & $\begin{array}{l}\text { Research on multicultural } \\
\text { education and the younger } \\
\text { generation }\end{array}$ & $\begin{array}{l}\text { not research on multicultural } \\
\text { education and the younger } \\
\text { generation }\end{array}$ \\
\hline Comparison & No comparison & - \\
\hline
\end{tabular}




\begin{tabular}{|l|l|l|}
\hline Result & $\begin{array}{l}\text { efforts to apply multicultural } \\
\text { education to the younger } \\
\text { generation to shape the moral } \\
\text { and character of the nation }\end{array}$ & $\begin{array}{l}\text { not an effort to apply } \\
\text { multicultural education to the } \\
\text { the moral and character of the } \\
\text { nation }\end{array}$ \\
\hline $\begin{array}{l}\text { Types of research and types of } \\
\text { publications }\end{array}$ & $\begin{array}{l}\text { Qualitative research published } \\
\text { in google scholar }\end{array}$ & $\begin{array}{l}\text { not qualitative research and } \\
\text { not published in google } \\
\text { scholar }\end{array}$ \\
\hline year of publication & $2019-2021$ & below 2019 \\
\hline language & Indonesian and English & Not Indonesian and English \\
\hline
\end{tabular}

\section{RESULT}

The authors present the results of the study obtained from 10 journals on multicultural education and the younger generation in the following table.

\begin{tabular}{|c|c|}
\hline Citation & Research Results \\
\hline (Gregorius We'u, 2020) & $\begin{array}{l}\text { Emphasizing the values of multicultural } \\
\text { education, namely collectivity, connectivity, } \\
\text { responsiveness, inclusivity, and universality }\end{array}$ \\
\hline (suneki, 2021) & $\begin{array}{l}\text { Multicultural education is essential to the } \\
\text { younger generation as a mindset and action in } \\
\text { dealing with societal problems in Indonesia. }\end{array}$ \\
\hline (Raga Cipta Prakasih, 2021) & $\begin{array}{l}\text { The application of multicultural education as a } \\
\text { implementation of the character education of } \\
\text { the nation's children needs to be applied } \\
\text { massively, structured, and systematically to } \\
\text { increase the sense of nationalism and eliminate } \\
\text { radicalism in the Indonesian nation. }\end{array}$ \\
\hline
\end{tabular}


(Patma Tuasikal, 2021)

(Nugraha et al., 2020)
Pandemic covid-19 brings significant changes in the order of human life, including the education sector. Cultural competency improvement can counterbalance a changing learning system as our driver adapts and develops in a new cultural environment. Therefore, the national education system needs to revive multiculturalism education through the systematic and competent development of pluralism.

The problem of pandemic covid-19 presents a new atmosphere in the national learning system. However, this does not decrease the spirit of educators in implementing multicultural education through online and offline learning, by oriented to 3 programs of multicultural learning activities, namely material-oriented programs, student-oriented programs, and socially oriented programs. 


\begin{tabular}{|l|l|}
\hline (Lara Sati, 2021) & $\begin{array}{l}\text { establishing citizenship education in this } \\
\text { educational curriculum can foster multicultural } \\
\text { values in students. Citizenship education is one } \\
\text { way in shaping the character and morals of the } \\
\text { nation's children. }\end{array}$ \\
\hline (Munaya Ulil Ilmi, Indah Mayangsari, 2021) & $\begin{array}{l}\text { Teachers are educators who play an essential } \\
\text { role in the education system. Teaching } \\
\text { multicultural education can use discussion } \\
\text { methods to provide an understanding of } \\
\text { pluralism in Indonesia. }\end{array}$ \\
\hline (Nurmansyah, 2019) & $\begin{array}{l}\text { Globalization challenges a teacher in carrying } \\
\text { out his role as an educator, including } \\
\text { advancing science and technology, moral } \\
\text { crisis, social crisis, and national and state } \\
\text { identity crisis because of the lack of } \\
\text { appreciation of the younger generation on } \\
\text { Indonesia's potential. }\end{array}$ \\
\hline (Jamhuri, 2019) & $\begin{array}{l}\text { Multicultural values also exist in the Quran, } \\
\text { including inclusive values and humanism, the } \\
\text { value of tolerance, and the value of } \\
\text { deliberation }\end{array}$ \\
\hline $\begin{array}{l}\text { Inclusive pluralist values (open in accepting } \\
\text { differences) have been implemented in Ngalah } \\
\text { pesantren as a form of character-building } \\
\text { strategy through multicultural civility. }\end{array}$ \\
\hline
\end{tabular}

\section{Young Generation and Multicultural Education}

The younger generation is the hope for the Indonesian because they are the future successors of the country. The younger generation must develop its potential to create a high-quality generation. That way, the younger generation can achieve the hopes and ideals of the Indonesian nation. The symbol of Indonesia, "Bhineka Tunggal Ika," indicates that Indonesia is a country that has a wide diversity, including race, ethnicity, culture, religion, language. It can be used as a character but often causes a conflict between races, tribes, groups, and beliefs. Millennials need a multicultural education to gain a broad and critical understanding of the plurality that exists in the country (3).

Multicultural education is a progressive educational approach by transforming education and criticizing the weaknesses in education. It is discrimination. Multicultural education aims to create equal opportunities in education for all students and citizens who have different races, ethnicities, cultures, religions, and social classes. Multicultural education provided early on can help prepare knowledge, skills, and mature attitudes to children in carrying out the role of a democratic citizen in the community to interact, negotiate and communicate with diverse groups to create a moral society order(1,2). Multicultural education can answer the challenges of changing times in this 
era of globalization because multiculturalism can connect and bridge that accommodate societal differences. With this educational model, Indonesian people, especially the younger generation, can accept, appreciate and tolerate multiculturalism in Indonesia. Through this diversity, the younger generation needs to instill the values of multicultural education in daily life, including democracy, pluralism, and humanism.

\section{DISCUSSION}

\section{The Importance of Multiculturalism Education}

When it comes to multicultural education, pluralism and culture are the keywords in explaining that definition. However, there is no definitive agreement on whether multicultural education has connotations on Indonesian cultural diversity or education that can form a character that can appreciate diversity. According to Kamanto Sunarto, multicultural education is the education of cultural diversity in the community or as an education aimed at fostering students' attitudes to appreciate the diversity of society (11). Multicultural education is a reform to create a change in the world of education for students. The implementation of this multicultural education can reconstruct the structure of an unfair school. If there is injustice, racism, sexism in a society, then multicultural education will be challenging to achieve. According to Zamroni, multicultural education is an effort to create an equal and fair educational environment for all students, focusing on developing togetherness and cultural differences in society (6).

As for why we should teach multicultural education to citizens, especially the younger generation, including multicultural education to create education for all. Multicultural education provides awareness of our responsibilities as good citizens, and multicultural education teaches about how we behave in respecting human rights. Multicultural education has four core values. First, Multicultural education can make us appreciate the plurality of cultures in society better. Second, multicultural education recognizes human dignity and human rights. Third, multicultural education builds our sense of responsibility as citizens. Four, multicultural education can develop our understanding of responsibility as human beings on the earth.

Based on these four values, we can formulate the objectives of multicultural are education developing a diversity of historical perspectives arising from community groups, strengthening awareness of diverse cultures in society, strengthening the intercultural competence of cultures in society, eliminating racism, sexism, and various other prejudices, developing understanding to pay more attention to the preservation of the planet earth, and developing skills in dealing with symptoms and social problems (12).

The following is the importance of multicultural education in Indonesia, namely as a means of solving socio-cultural conflicts, as an effort to preserve culture to the younger generation by providing a broad and deep understanding of Indonesian culture, and multicultural education can be the foundation of the development of the educational curriculum. 


\section{Efforts to Improve The Morale of the Indonesian Nation}

The rise of insulting cases on social media is a reflection of the moral breakdown of millennials. For example, teenagers often give inappropriate criticism or hate speech about their culture, ethnicity, beliefs, appearance. That is an unappreciative attitude. Therefore, we must improve the morale of the younger generation because they are the future successors of the Indonesian nation.

a. Citizenship Education

One of the efforts to realize multicultural education is to apply citizenship education in the learning process. Citizenship education can change the perspective or paradigm of students to the phenomenon of diversity that often occurs today. Citizenship education is relevant in applying multicultural values. The education provided can teach students about maintaining and appreciating diversity and national unity based on nationalism, patriotism, tolerance, and religious attitudes. The purpose of citizenship education is to preserve the nation's diversity to minimize practices that lead to violent conflicts, conflicts containing elements of SARA, oppression, and discrimination.

Citizenship education plays a vital role in shaping the morale of the nation's children. By having high morality, millennials can avoid horizontal conflicts committed by irresponsible people because it can interpret a phenomenon related to the reality of Indonesian diversity (13). Given that Indonesia has the nation's variety, it is expected that through citizenship, education can form the nation's morality that prioritizes national integration, preserving values and culture in the community, and maintaining the peace of society. To realize all of that, the role of educators, namely teachers. The duties and functions of teachers in multicultural education are to form multicultural patterns, shape children's attitudes to mutual respect for the diversity of people's culture, develop a caring attitude towards the social environment, create an anti-discriminatory perspective on race, ethnicity, and culture(6)

b. Religious Education

In addition to providing citizenship education to students, Islamic education also plays a vital role in applying the values of multicultural education. Providing Islamic education to students aims to form a person by the guidelines contained in the Quran and hadith, namely by developing all the potential owned by humans and fostering a harmonious relationship between each human being and Allah Swt. The Quran mentioned the values - multicultural values taught to humans, including

1. Values of humanism and inclusiveness

Differences in society create vulnerability to social conflicts. Conflict can happen because of the lack of ability to accept and appreciate the differences in ideas, ideas, opinions, and works of others, a shared sense of social solidarity, and a lack of social sensitivity and selfishness. Therefore, inclusive values, humanism, mutual respect, and love are needed to prevent social conflict.

2. Tolerance value

Tolerance is defined as respect and respect for each other, beliefs and beliefs, and dissent. The younger generation needs tolerance to interact in daily interactions.

3. Value of deliberation

Deliberation can form a democratic attitude and be open to differences. Attach importance to consideration for consensus in addressing problems to realize the 
common interest. The principle of togetherness, kinship, and brotherhood takes precedence in deliberation to realize a peaceful and dignified society.

4. The Value of Justice

The value of justice taught in Islam can form empathy towards others and encourage social sensitivities. By prioritizing justice, people feel the same degree in establishing social relations and fostering a sense of anti-discrimination that often occurs in Indonesia (9).

c. Utilization of information technology

There are specific strategies that can be applied to millennials in building the values of multicultural education. The development and progress of science and technology make opportunities in instilling multicultural values. According to Prof. Arry Bainus, flexibility must be done in investing the importance of multicultural education, such as democratic, humanism, tolerance, and cooperation, because the method of doctrine is seen as incompatible with the thinking of millennials. Utilizing social media platforms or other technologies to disseminate multicultural values is considered an effective method. Given that social media and internet users increase every year, we can spread and share stories about our experiences in practicing these multicultural values every year.

\section{CONCLUSION}

The diversity of culture owned by the Indonesian nation poses a vulnerability to social conflicts that can trigger the disunity of the Indonesian country. The rise of riots caused by the plurality is a form of expression of primordialism and community fanaticism, which can happen due to a lack of knowledge and understanding of the establishment of the Republic of Indonesia. As the future successor of the nation, the younger generation should have a deep and broad understanding of multiculturalism not to be easily caught up in horizontal conflicts caused by irresponsible individuals. Therefore, the importance of applying the values of multicultural education to the younger generation in shaping morals and strong character in this digital era. Multicultural education is used to solve socio-cultural conflicts and preserve culture for the younger generation by providing a broad understanding of the culture. The younger generation does not forget its cultural origin. In addition, multicultural education can be used as a foundation for developing an educational curriculum in creating democratic learners.

Efforts to apply the values of multiculturalism obtained from citizenship education and religious education involved in the national education curriculum and utilize information technology to spread things related to the values - values of multicultural education to the broader community to be able to appreciate diversity, unity, and unity of the nation based on the attitude of nationalism, patriotism, tolerance, and religious 


\section{REFERENCES}

1. Gregory We'u. The Urgency of Multicultural Education: an Answer to The Problem of Plurality. 2020;4(2):71-5.

2. Suneki HS. Multicultural Education In Anticipation of Social Problems in Indonesia. 2021;x(1):54-61. Available from: http://103.98.176.9/index.php/civis/article/view/8191

3. Raga Cipta Prakasih F and R. Values Of Nationalism And Anti-Radicalism In Multicultural Education. 2021;2(2):294-303.

4. Patma Tuasikal. The Role of Multiculturalism Education in Preventing Culture in the era of pandemic covid 19. 2021;02(1):42-9.

5. Nugraha MT, Hidayatullah Y, Ruswandi U, Erihadiana M. Implementation of Multicultural Education in the Adaptation of New Habits (Akb). 2020;12(2):138-48.

6. Larasati DAD. The Role of Citizenship Education in Multicultural Education. Multicultural Educators [Internet]. 2021;5(1):904-9. Available from: http://ppkn.org/wpcontent/uploads/2018/01/PROSIDING-FULL-RUANG-baruI.pdf\#page=126

7. Nurmansyah. Teacher Challenges in the Millennial Era. 2019;

8. Munaya Ulil Ilmi, Indah Mayangsari FADU. The Role of Teachers in The Teaching of Multicultural Education: Initiation and Practice. 2021;4(2):71-6.

9. Jamhuri M. Islamic Religious Education Learning Model in Shaping Multiculturalism Attitudes. Multicultural Educators. 2019;3(1):63.

10. Yusuf A. Strategy of Forming Inclusive-Pluralist Character Through Multicultural Kiai In Pesantren Ngalah Pasuruan. Multicultural Educators. 2019;3(1):1.

11. Rosyada D. Multicultural Education In Indonesia A Conceptual View. SOSIO Didakt Soc Sci Educ J. 2019;1(1).

12. Wulandari T. concept and praksis multicultural education. 1st ed. Yogyakarta: UNY Press; 2020. 1-100 p.

13. Nanggala A. Citizenship Education as a Multicultural Education. J Soshum Incentives. 2020;3(2):197-210. 